\title{
The Continuous Culture of Anaerobic Bacteria
}

\author{
By P. N. HOBSON AND R. SUMMERS \\ The Rowett Research Institute, Bucksburn, Aberdeen
}

(Accepted for publication 9 November)

\begin{abstract}
SUMMARY
Modifications to an anaerobic continuous culture apparatus to allow $\mathrm{pH}$ control, and $\mathrm{pH}$ and $\mathrm{Eh}$ measurements, are described. Two anaerobic rumen bacteria were grown under different conditions, but as carbohydrate-limited cultures. The effects of growth rate, $\mathrm{pH}$ value and $\mathrm{Eh}$ value on yields of bacteria, enzyme activities and fermentation products are described. Optimum bacterial yields per mole of substrate fermented and per mole of ATP presumably formed in the fermentation were variable with the particular bacterium and the substrate, and were high for hexose fermentations. Yields of bacteria varied with growth rate, being lowest at low growth rates. Fermentation products also varied with growth rate and the $\mathrm{pH}$ value of the culture in some cases, as did the production of enzymes. Maximum growth rates calculated from batch cultures were in agreement with those found in the continuous cultures.
\end{abstract}

\section{INTRODUCTION}

Some results obtained from continuous cultures of anaerobic rumen bacteria were described by Hobson (1965a). We give here some further observations on continuous cultivation of anaerobic bacteria in a chemostat with external $\mathrm{pH}$ control.

\section{METHODS}

Apparatus. The apparatus described by Hobson (1965b) relied for $\mathrm{pH}$ control on the buffering action of the medium, but it was mentioned that external $\mathrm{pH}$ control had been incorporated in a later modification of the apparatus. The present apparatus, which has been in use for some years, is basically the same as that previously described (Hobson, 1965b) with the following modifications (reference is made to Fig. 1, Hobson, $1965 b$, in this description.) The single gas flow-meter (P) has been replaced by a double flow-meter on the 'apparatus' side of the furnace. This enables not only the oxygenfree carbon dioxide from the furnace to be monitored, but also a stream of some other gas, such as oxygen, to be introduced into the gas flow. In place of the balloon A a carbon-dioxide line is taken from the junction $\mathrm{N}$ to the filter at $\mathrm{A}$ to replace medium in flask B by carbon dioxide as the flask is emptied. This lead is clipped off close to A when the flask is to be changed, to obviate entry of air into the tubing. The culture vessel $\mathrm{F}$ has been replaced by one of similar design but of $250 \mathrm{ml}$. working volume, and the stirring gas flow increased to $250 \mathrm{ml}$./ $\mathrm{min}$. The rubber bung forming the top of the vessel is now as follows. A large diameter hole is bored centrally through the rubber bung and through this is inserted a combination glass-calomel electrode (E.I.L., type SHDN33. Electronic Instruments Ltd., Richmond, Surrey). This has a rubber sleeve part-way up it which, greased with silicone grease, makes the electrode a gas-tight fit 
in the hole and allows the electrode to be inserted without damage to the glass tip. Arranged around this are the inlet and sampling tubes shown in the original diagram and also inlets for alkali and acid. These latter are stainless steel tubes of $\frac{1}{8}$ inch $(0.32 \mathrm{~cm}$.) outside diameter to the projecting tops of which are soldered steel tubes of larger diameter into which fit smaller tubes in the manner of a cone and socket joint. Also inserted through a further hole so that the silicone-greased ebonite cap is about $\frac{1}{2}$ inch $(1.27 \mathrm{~cm}$.) into the bung is an E.I.L. platinum electrode type EPT 23 . The steel tubing joints on the acid and alkali inlets are connected to small bore glass tubes which pass via stopcocks to rubber tubing which can be opened or closed by a Pye titrator delivery unit (Pye Instruments, Cambridge) adjusted so that each solenoid opens to the same extent. The upper ends of these tubes are connected to glass joints and then by glass tubing to alkali and acid reservoirs at a height of about 18 inches $(45 \cdot 7 \mathrm{~cm}$.) above the culture vessel. Sterile air is admitted to these reservoirs through cottonwool plugs and 'Carbosorb'-containing tubes. The platinum electrode circuit is a recent addition and was not used in all the experiments reported here, and may be omitted. The glass electrode is connected to an E.I.L. pH meter/controller model $91 \mathrm{~B}$, and the platinum electrode to a similar instrument graduated in millivolts (this is at present used only as a meter). The calomel reference electrode can be connected by means of a switch to either the $\mathrm{pH}$ meter or the millivoltmeter in circuit with either the glass or platinum electrode. The $\mathrm{pH}$ meter is also connected to a 'Dwarf' recorder (Everett-Edgcumbe Ltd., Colindeep Lane, London), and via the upper and lower controller circuits to the solenoids actuating the inflow of acid or alkali. In use the lower indicator of the $\mathrm{pH}$ meter/controller is set at the appropriate $\mathrm{pH}$ value. In most cases control necessitates only the addition of alkali as fermentation tends to lower the $\mathrm{pH}$ value of the culture medium (from its initial value $\mathrm{pH} \mathrm{6.8)}$ ) and the upper indicator is set about 0.2 units higher to act mainly as a safety device. The taps on the alkali and acid lines are then set by trial so that a very small amount of alkali is added at each opening of the solenoid valve and overshoot of $\mathrm{pH}$ is negligible. When an $\mathrm{Eh}$ measurement is to be made the $\mathrm{pH}$ meter is returned to the check point (after moving the upper control setting if necessary), the reference electrode is switched to the millivoltmeter and this is then set to the 'read' position. A stable Eh reading is usually obtained in about $5 \mathrm{~min}$. and during this time the $\mathrm{pH}$ of the culture does not alter appreciably. To resume $\mathrm{pH}$ control the procedure is then reversed. This circuit was adopted so that a separate reference electrode need not be inserted in the culture vessel, but if the Eh value were to be continually recorded then a second electrode would be needed. No 'poisoning' of the platinum electrode by culture constituents has been noted in runs lasting many hundreds of hours.

Originally a $\mathrm{pH}$ controller working by mechanical contacts on a 'slave' meter operated by a Pye $\mathrm{pH}$ meter was used in the circuit, but the contacts on this were liable to stick in the 'on' position and breakdowns were comparatively frequent. The E.I.L. meter/controller is much more compact and reliable, and extremely stable.

All the parts of the apparatus including the solenoid valve tubings and the acid and alkali reservoirs and the acid and alkali solutions are sterilized by autoclaving $\left(120^{\circ}, 25 \mathrm{~min}\right.$.) and assembled aseptically. The two electrodes are sterilized by immersion for $24 \mathrm{hr}$ in a solution of $1 \%(\mathrm{v} / \mathrm{v}) \mathrm{H}_{2} \mathrm{SO}_{4}$ in $70 \%(\mathrm{v} / \mathrm{v})$ ethanol in water. This treatment has had no adverse effects on the electrodes, and no contamination of the cultures attributable to the electrodes has occurred. The $\mathrm{pH}$ meter is initially 
standardized with a second electrode system and external buffers, the culture electrode is then connected up and the $\mathrm{pH}$ of the uninoculated medium determined. This can then be checked against the $\mathrm{pH}$ value of a sample of the medium measured on an external $\mathrm{pH}$ meter. The check point of the $\mathrm{pH}$ meter is noted at about weekly intervals during a run, but usually drift amounts to only about $0.1 \mathrm{pH}$ units per fortnight.

In some chemostat $\mathrm{pH}$ control systems (e.g. Wright, 1960) a timer is used to add the acid or alkali at short intervals during the 'on' cycle. With the taps in the alkali/ acid addition circuit as described here the rate of addition of the solutions $(3 \% \mathrm{NaOH}$, $\mathrm{w} / \mathrm{v}$, or $\mathrm{H}_{2} \mathrm{SO}_{4}, \mathrm{v} / \mathrm{v}$ ) can be adjusted so that overshoot is negligible and our $\mathrm{pH}$ control is to better than 0.1 unit. Some adjustment of the relative positions of the acid and alkali inlets and the glass electrode may be needed to get optimum control.

A difficulty of growing the anaerobic bacteria used in the present work is the diffusion of air through the rubber tubing used in the medium circuits. This is negligible with some rubbers, but with other rubber tubings we have found that although air diffusion may not oxidize the medium to the point where a trace of the pink resazurin colour is seen, it can still increase the Eh value sufficiently to stop the growth of some organisms. Since rubber tubings, even from the same supplier, seem to vary from batch to batch we have not found any that can be unequivocally recommended. Neoprene is the best we have so far used, but this may split on autoclaving. Hungate (1963) and Hungate, Smith \& Clarke (1966) have also considered the problem of diffusion of oxygen through rubber in anaerobic cultures. The latter authors recommend butyl rubber stoppers for culture tubes. The wall thickness of the tubing should be as great as possible consistent with flexibility. Although much of the tubing may be of glass or stainless steel some rubber is needed, in parts, to give flexibility to take up strains and vibrations in the apparatus (and during autoclaving) and to allow joints to be connected.

Bacteria. The lipolytic Bacterium $5 \mathrm{~S}$ was the strain previously used and described by Hobson (1965a). Two strains of Bacteroides amylophilus were isolated by our colleague Dr T. H. Blackburn and were similar to the strains of B. amylophilus described by Blackburn \& Hobson (1962). This bacterium ferments only starch, dextrins or maltose and is one of the more important proteolytic bacteria in the rumen, producing amylase and protease, both excreted into the culture medium.

Media. The medium for growth of bacterium $5 \mathrm{~S}$ on glycerol in an atmosphere of $100 \% \mathrm{CO}_{2}$ was described by Hobson (1965a). For fructose growth the glycerol was replaced by fructose. When $95 \%(\mathrm{v} / \mathrm{v}) \mathrm{N}_{2}+5 \%(\mathrm{v} / \mathrm{v}) \mathrm{CO}_{2}$ was used as atmosphere the sodium bicarbonate concentration in the medium was decreased to $0.02 \%(\mathrm{w} / \mathrm{v})$, and the cysteine hydrochloride solution brought to $\mathrm{pH} 6.6$ with sodium hydroxide solution before the bicarbonate and carbohydrate were added and the solution filter-sterilized. In batch cultures under this atmosphere $\mathrm{M} / 60$ phosphate buffer ( $\mathrm{pH} 6 \cdot 6)$, was included to help to control the culture $\mathrm{pH}$ value. For incubations under an atmosphere of $100 \% \mathrm{~N}_{2}$ bicarbonate was omitted from this medium. The medium for batch and continuous culture growth of Bacteroides amylophilus (formulated by $\mathrm{Dr} \mathrm{T}$. H. Blackburn to give optimum growth in batch cultures) contained, per $100 \mathrm{ml}$; mineral solutions $a$ and $b$ (Hobson, 1965a), $15 \mathrm{ml}$. each; Bacto tryptose, $0 \cdot 1 \mathrm{~g}$.; cysteine hydrochloride, $0.1 \mathrm{~g}$.; sodium bicarbonate, $0.6 \mathrm{~g}$.; resazurin, $0.1 \mathrm{ml}$. of $0.1 \%$ solution; maltose hydrate (B.D.H.), to concentration required; water to $100 \mathrm{ml}$. Stock cultures were kept on slopes of this medium solidified with $2 \%$ agar. This bacterium will grow 
in a medium containing ammonia as sole nitrogen source, but the addition of tryptose to the medium appeared to decrease the lag phase in batch cultures, although no utilization could be shown (Blackburn, 1965).

General methods of preparing the media and of setting up and inoculating the continuous culture apparatus have been previously described (Hobson, 1965a), except that in the later work with Bacteroides amylophilus the maltose, bicarbonate and cysteine were added as concentrated filter- or heat-sterilized separate solutions and not as a mixed filter-sterilized solution.

Analytical methods. Methods of sampling the cultures and of determining dry weights of bacteria, glycerol, total volatile fatty acids (VFA), lactic acid and culture turbidity were as previously described (Hobson, 1965a). Succinic acid was determined by a manometric method (Umbreit, Burris \& Stauffer, 1957). Fructose was determined by the method of Roe (1934) and maltose by the Somogyi-Nelson method (Nelson, 1944). Volatile fatty acids were separated by gas chromatography (on an instrument made by Gas Chromatography Ltd., Maidenhead) by our colleague Mr T. Walker. Bacterialnitrogen was determined by a Kjeldahl method on bacteria centrifuged down from the culture at $0^{\circ}$ and washed once with water at $0^{\circ}$. Total medium-nitrogen was determined by a Kjeldahl method and ammonia-nitrogen by a microdiffusion method. Lipase and esterase activities were determined by using naphthyllaurate or acetate as substrates at pH 6.8 (Hobson \& Summers, 1966). Protease activity was determined by a modification of the method of Anson (1938) as used by Blackburn (1965), with casein as substrate. Amylase activity was determined by a modification of the method of Walker \& Campbell (1963), again as used by Blackburn (1965). Total counts of Bacterium 5S were made on a Coulter Counter (Coulter Electronics Ltd., Dunstable, England) with a $30 \mu$ orifice tube at an aperture current setting of 8 and a threshold value of 20 after suitable dilution of the culture in $0.9 \%(\mathrm{w} / \mathrm{v}) \mathrm{NaCl}$ solution. Bacteroides amylophilus was counted at a threshold value of 35 . In all cultures, batch and continuous, the culture turbidity was found to have a linear relationship to bacterial dry weight $(\mathrm{mg}$. $/ \mathrm{ml}$.) except at very low values of turbidity (about 3 turbidity units) and turbidity was used to monitor the continuous cultures. However, nearly all values of bacterial yields were calculated from actual dry weight measurements and not from turbidity readings.

Growth in the basal media, without carbohydrate, was so small that no accurate estimate of bacterial concentration either by weight or turbidity could be made and this degree of basal growth was neglected in calculating yields.

The definitions of bacterial yields, $Y_{\text {substrate }}$ and $Y_{\text {ATP }}$, are as proposed by Bauchop \& Elsden (1960) and as used in the previous paper (Hobson, 1965a).

In all cases there were slight variations in substrate concentrations in the different lots of medium used during each continuous culture run and in different cultures. The nominal concentration of sugar is given, but values for $Y$ and fermentation products are calculated on the analysis of the medium flowing through the culture at any particular time.

The rate of alkali addition to the cultures at $\mathrm{pH}$ values about 6-6.5 was small, about $5 \%$ of the medium flow rate; dilution rates are given as the actual medium flow rate.

All cultures were incubated at $39^{\circ}$. 


\section{RESULTS}

\section{Lipolytic Bacterium $5 S$}

Culture on glycerol. Batch cultures showed that glycerol-limited cultures could be run at a glycerol concentration of $59.7 \mu \mathrm{mole} / \mathrm{ml}$. (Hobson, 1965 a); Fig. 1 shows some results from a continuous culture of $1660 \mathrm{hr}$ duration at this glycerol concentration under an atmosphere of $\mathrm{CO}_{2}$. The $\mathrm{pH}$ value was controlled at $\mathrm{pH} 6 \cdot 1$ and, as in all the cultures described, at least $30 \mathrm{hr}$ were allowed for the cultures to stabilize at a particular growth rate before measurements were begun. The optimum dilution rate (D) shown is about $0.2 \mathrm{hr}^{-1}$, but when the medium flow was held at $D 0.19 \mathrm{hr}^{-1}$ and the $\mathrm{pH}$ value decreased to 5.5 the culture rapidly washed out. At this dilution rate $\left(0.19 \mathrm{hr}^{-1}\right)$ at

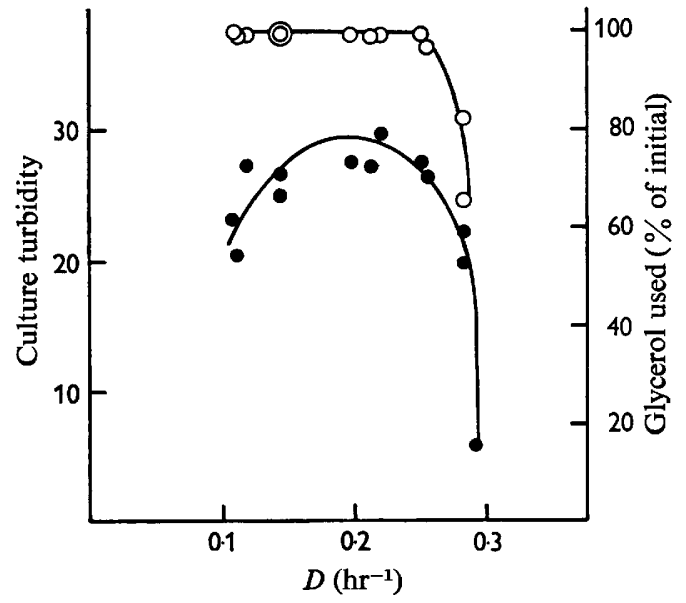

Fig. 1

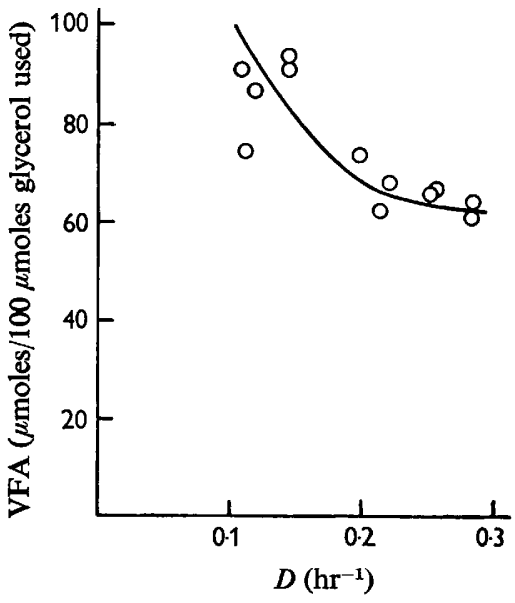

Fig. 2

Fig. 1. Culture of Bacterium 5S on glycerol. Culture turbidity 9 . Glycerol used $\bigcirc$. Results from one culture of $1660 \mathrm{hr}$ duration. A turbidity of 20 is equivalent to $0.79 \mathrm{mg}$. dry wt bacteria $/ \mathrm{ml} . D$ in all figures $=$ dilution rate.

Fig. 2. Culture of Bacterium $5 \mathrm{~S}$ on glycerol. Volatile fatty acid (VFA) production. Results from culture shown in Fig. 1.

$\mathrm{pH}$ values above 7 the culture slowly washed out and at $\mathrm{pH} 7 \cdot 4$ when the dilution rate was changed to $0.21 \mathrm{hr}^{-1}$ a rapid washout took place. Over the range $\mathrm{pH} 6$ to 7 at $D 0.2 \mathrm{hr}^{-1}$ no differences in bacterial yield were found. Lipase and esterase activities were measured at different growth rates and two peaks of activity (coincident for lipase and esterase) in both bacteria and supernatant fluid were found at dilution rates of about $0.24 \mathrm{hr}^{-1}$ and $0 \cdot 1 \mathrm{hr}^{-1}$. The lipase activity of the bacteria showed a maximum at $\mathrm{pH} 6.6$ when tested at four culture $\mathrm{pH}$ values. This organism produced acetic, propionic and succinic acids and a little lactic acid when fermenting glycerol (Hobson, $1965 a$ ); a change in the proportion of the volatile fatty acids with growth rate is shown in Fig. 2. There was a suggestion of a small increase in amounts of fatty acids formed as the culture $\mathrm{pH}$ changed from 6 to 7 at $D 0.2 \mathrm{hr}^{-1}$.

Batch cultures with different concentrations of glycerol were incubated under atmospheres of oxygen-free $\mathrm{CO}_{2}, \mathrm{~N}_{2}+\mathrm{CO}_{2}(95+5)$ and $\mathrm{N}_{2}$. At a glycerol concentra- 
tion of $28.3 \mu \mathrm{moles} / \mathrm{ml}$. growth was equally rapid in all media and $98 \%$ of the glycerol was utilized. However, at glycerol concentrations above this, lack of buffering capacity in the media under $\mathrm{N}_{2}+\mathrm{CO}_{2}$ or $\mathrm{N}_{2}$ caused a decrease to about $\mathrm{pH} 5 \cdot 6$, when growth ceased before all the glycerol was utilized. In the medium under $100 \% \mathrm{CO}_{2}$ glycerol up to $76 \mu \mathrm{moles} / \mathrm{ml}$. was utilized. The yield of bacteria per mole of glycerol fermented was similar in all cultures (about 17). These results showed that high concentrations of carbon dioxide were not essential for growth of the bacterium $5 \mathrm{~S}$, so continuous cultures were conducted with the medium as before but with the sodium bicarbonate concentration decreased to $0.02 \%(\mathrm{w} / \mathrm{v})$ and with a gas phase $\mathrm{N}_{2}+\mathrm{CO}_{2}(95+5)$. The results of two cultures of 300 and $400 \mathrm{hr}$ duration are combined in Fig. 3. One culture

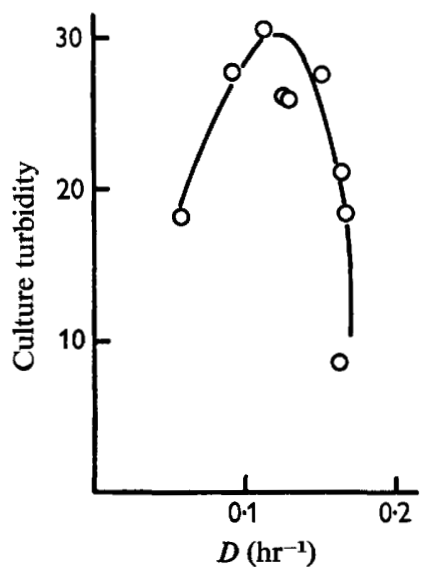

Fig. 3

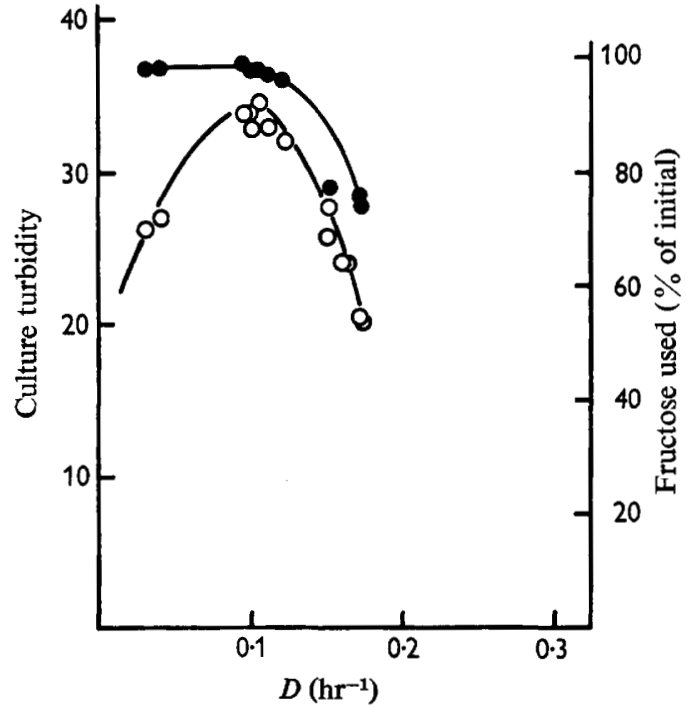

Fig. 4

Fig. 3. Culture of Bacterium 5S on glycerol under an atmosphere of $\mathrm{N}_{2}+\mathrm{CO}_{2}(95+5$ by vol.). Results from two cultures of $300 \mathrm{hr}$ and $400 \mathrm{hr}$ duration. A turbidity of 20 is equivalent to $0.90 \mathrm{mg}$. dry wt bacteria $/ \mathrm{ml}$.

Fig. 4. Culture of Bacterium $5 \mathrm{~S}$ on fructose. Culture turbidity $O$. Fructose used $\bigcirc$. Results from a culture of $1150 \mathrm{hr}$ duration. A turbidity of 20 is equivalent to $0.92 \mathrm{mg}$. dry wt bacteria/ml.

was controlled at $\mathrm{pH} 6.2$ and the other at $\mathrm{pH} 6.5$. When the culture was changed to pH 5.4 at $D 0.12 \mathrm{hr}^{-1}$ a rapid washout occurred. In the culture at $\mathrm{pH} 6.5$ the values of $Y_{\text {glycerol }}$ were, at $D 0.057 \mathrm{hr}^{-1}, 15.8 ; D 0.092 \mathrm{hr}^{-1}, 16.1 ; D 0.128 \mathrm{hr}^{-1}, 20.2$, and volatile fatty acids produced were over $90 / 100 \mu$ moles glycerol used. Glycerol used was $97 \%$ of that added at dilution rates about $0 \cdot 1 \mathrm{hr}^{-1}$.

Culture on fructose. Batch cultures containing different concentrations of fructose showed that the growth of Bacterium $5 \mathrm{~S}$ was proportional to fructose used at concentrations of fructose up to $30.6 \mu \mathrm{moles} / \mathrm{ml}$. Above this concentration $\mathrm{pH}$ changes stopped growth before all the fructose was utilized. The fermentation products were in all cases acetic and propionic acids at a total of $200 \mu \mathrm{moles} / 100 \mu$ moles fructose used and in the amounts $55 \mu$ moles acetic acid and $145 \mu$ moles propionic acid. Growth between 18 and 
$24 \mathrm{hr}$ of incubation was logarithmic. A value for growth rate between these times was calculated by using the equation

$$
\mu t=2.303\left(\log n-\log n_{0}\right),
$$

where $n$ and $n_{0}$ were determined from the graph of culture turbidity against total count (see below). With increasing initial concentration of fructose (nominally $0 \cdot 1,0 \cdot 2,0 \cdot 4$, $1 \cdot 0,2 \cdot 0 \%, \mathrm{w} / \mathrm{v}$ ) values for $\mu$ of $0 \cdot 108,0 \cdot 123,0 \cdot 125,0 \cdot 167,0 \cdot 161 \mathrm{hr}^{-1}$ were obtained.

Continuous cultures of Bacterium $5 \mathrm{~S}$ were run at a fructose concentration of $27.8 \mu \mathrm{moles} / \mathrm{ml}$. The results from a culture of $1150 \mathrm{hr}$ duration at $\mathrm{pH} 6.2$ are shown in Fig. 4. Total counts were made on a number of samples from this culture; Fig. 5 shows that total bacterial numbers were in linear relationship to bacterial mass con-

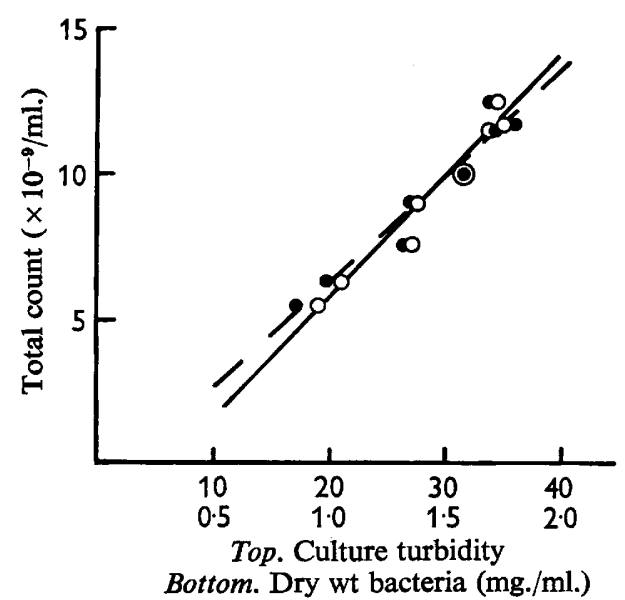

Fig. 5

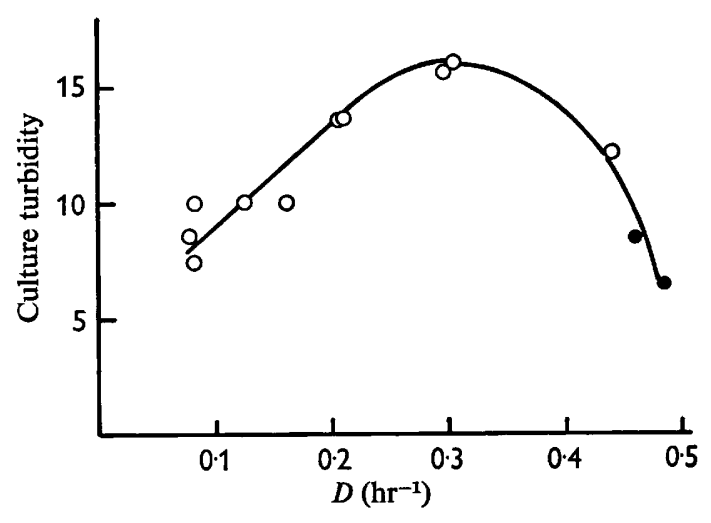

Fig. 6

Fig. 5. Culture of Bacterium 5S on fructose. Total count $\left(\times 10^{-9}\right)=0.42$ turbidity $-2 \cdot 7$. Culture turbidity $O$. Total count $\left(\times 10^{-9}\right)=7 \cdot 31$ dry bacteria $-1 \cdot 0$. Bacterial dry weight 0 .

Fig. 6. Culture of Bacteroides amylophilus on maltose. Results from a culture of $890 \mathrm{hr}$ duration. A turbidity of 14 is equivalent to $0.9 \mathrm{mg}$. dry wt bacteria/ml. At points indicated a true steady state was not obtained (see text).

centration and to culture turbidity. The bacterial yield $\left(Y_{\text {tructose }}\right)$ increased to a maximum of 60 (average of four determinations) at dilution rates about $0 \cdot 1 \mathrm{hr}^{-1}$. The fermentation products were acetic and propionic acids in total amounts about $200 \mu \mathrm{moles} / 100 \mu$ moles fructose used at all dilution rates. No difference was found in culture turbidity at culture $\mathrm{pH}$ values of 6.2 and 6.5 at $D 0.08 \mathrm{hr}^{-1}$. At $D 0.1 \mathrm{hr}^{-1}$ changing the culture $\mathrm{pH}$ to 5.6 or 7.0 resulted in a slow washout of the cells.

\section{Bacteroides amylophilus}

Culture on maltose. Batch cultures of Bacteroides amylophilus at different maltose concentrations showed that growth was proportional to maltose used at concentrations up to $11.7 \mu \mathrm{moles} / \mathrm{ml}$. and above this concentration low $\mathrm{pH}$ values or lack of nitrogen limited the growth. The amount of maltose left at the end of the log phase of growth was similar in each culture and was about $0.82 \mu \mathrm{moles} / \mathrm{ml}$. When growth ceased lysis 
of the organisms was rapid and the culture turbidity decreased. Acetic, formic and succinic acids were formed. The total volatile fatty acids formed during the log phase of growth at all concentrations of maltose were similar and averaged $138 \mu$ moles/ $100 \mu$ moles maltose used; succinic acid was not determined quantitatively. The yields of bacteria per mole of maltose used $\left(Y_{\text {maltose }}\right)$ during the log phase of growth at different initial maltose concentrations from 2.04 to $11.7 \mu \mathrm{moles} / \mathrm{ml}$. were: 110,102 , $87,78,77$, respectively. Since the culture turbidity was small for this bacterium, B. amylophilus, an accurate determination of total count from culture turbidity was not possible at low concentrations of maltose in the batch cultures, but at higher concentrations where the culture turbidity corresponding to $n_{0}$ was higher, values for total counts and hence growth rates could be determined. These suggested a maximum value of $\mu$ of about $0.46 \mathrm{hr}^{-1}$.

Continuous cultures were run at a maltose concentration of $7 \cdot 6 \mu$ moles $/ \mathrm{ml}$. Figure 6 shows results from a run of $890 \mathrm{hr}$ at a culture at $\mathrm{pH} 6.4$. When the dilution rate was set above $0.443 \mathrm{hr}^{-1}$, at $D 0.460 \mathrm{hr}^{-1}$ and $0.485 \mathrm{hr}^{-1}$, the culture turbidity decreased rapidly to 8.5 and 6.5 units, respectively; but at each dilution rate the rapid decrease was followed by a slow decline at the rate of about 1 unit in $15 \mathrm{hr}$, so a true steady state was not achieved. At the dilution rate $0.485 \mathrm{hr}^{-1}$ the maltose remaining in the culture was $1.93 \mu \mathrm{moles} / \mathrm{ml}$. At the other dilution rates the average amount remaining was $0.58 \mu \mathrm{moles} / \mathrm{ml}$.; this corresponds to a maltose utilization of about $92 \%$.

Total counts of bacteria were made during continuous culture of Bacteroides amylophilus at different culture turbidities and dilution rates. A linear relationship was found between turbidity and total count; a turbidity of 8 corresponded to a total count of $3.4 \times 10^{9}$ bacteria $/ \mathrm{ml}$.

Figure 7 shows the values of $Y$ (per mole of maltose utilized) obtained during the above culture and during another of $1100 \mathrm{hr}$ duration. Figure 8 shows the volatile fatty acids formed at different dilution rates; these acids were identified as acetic and formic in equimolar amounts. The succinic acid, the only other fermentation product, formed was determined at two dilution rates. At $D 0.296 \mathrm{hr}^{-1}$ fermentation products, per $100 \mu$ moles maltose used, were $172 \mu$ moles formic acid, $172 \mu$ moles acetic acid and $159 \mu$ moles succinic acid. Assuming uptake of $\mathrm{CO}_{2}$ in succinic acid formation this gives a carbon recovery of $82.6 \%$. At $D 0.077 \mathrm{hr}^{-1}$ the products were $126 \mu$ moles formic acid, $126 \mu$ moles acetic acid and $201 \mu$ moles succinic acid, giving a carbon recovery of $81.7 \%$.

The Eh value of the medium as measured by the platinum and calomel electrode system was about $-100 \mathrm{mV}$. at $\mathrm{pH} 6.5$ (an actual reading of about $-350 \mathrm{mV}$.), and the resazurin was entirely colourless. At this Eh value growth of the bacteria took place, but this growth did not result in any decrease of the Eh value, and when the Eh value increased, for any reason, the growth of the bacteria ceased and they began to wash out. The bacteria appeared to have no capacity for reducing the medium even when a heavy concentration of bacteria was present, although a (presumptive) Bacillus contaminant rapidly decreased the Eh value, even when present only in small numbers.

The morphology of the Bacteroides amylophilus bacteria in batch and continuous cultures varied from small cocci to small rods, with sometimes some of the irregularly shaped bacteria first noted by Hamlin \& Hungate (1956). The number of irregularshaped organisms increased under adverse conditions, such as high Eh value or low 
$\mathrm{pH}$ value at the end of batch cultures; but the coccoid or rod-like morphology appeared to be independent of the growth rate. The same relationship between culture turbidity and bacterial dry weight was found whether the bacteria were predominantly coccoid or rod-shaped. The bacteria were capsulated at all times, but at dilution rates round about $0.3 \mathrm{hr}^{-1}$ the culture foamed more than at lower or higher rates, and this seemed to be associated with an increase in capsule and slime production, although no marked difference in the nitrogen content (about $9-10 \%$ of the dry weight) could be found in bacteria grown at dilution rates of $0.148,0.222$ and $0.354 \mathrm{hr}^{-1}$.

During two continuous cultures of Bacteroides amylophilus determinations were made of bacterial-nitrogen and total-nitrogen in culture supernatant fluid and inflowing medium and ammonia-nitrogen in culture supernatant fluid and medium. Six

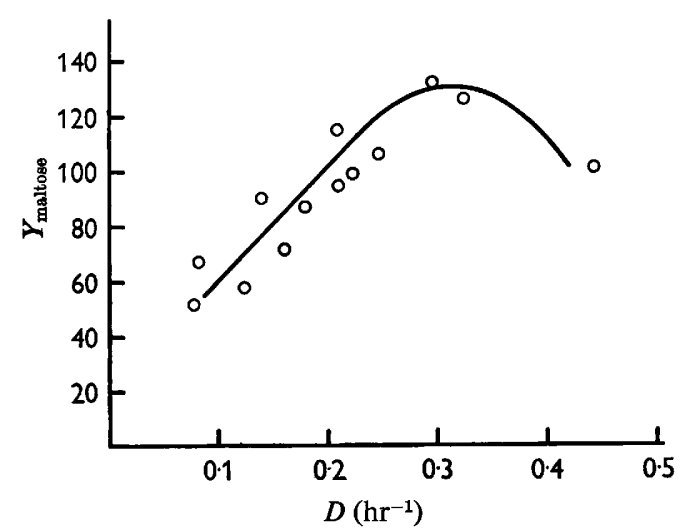

Fig. 7

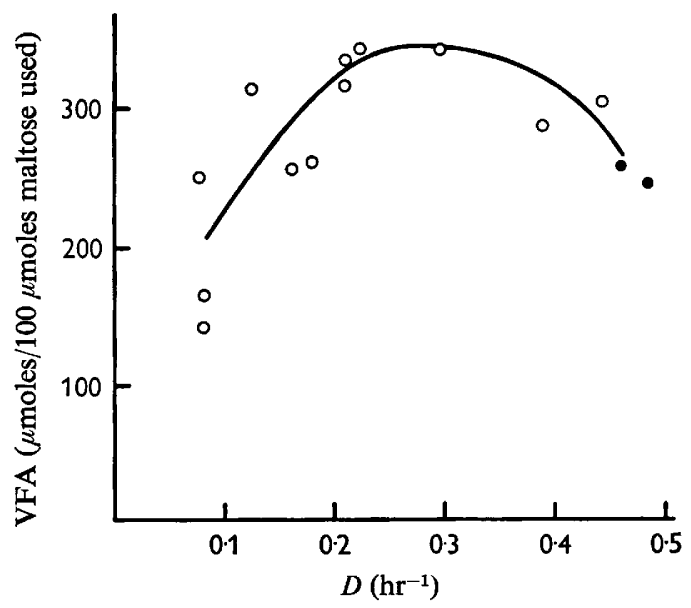

Fig. 8

Fig. 7. Culture of Bacteroides amylophilus on maltose. Results from two cultures of $890 \mathrm{hr}$ and 1100 hr duration. $Y_{\text {maltose }}$ is calculated on the basis of maltose used, not just that fermented (see text).

Fig. 8. Culture of Bacteroides amylophilus on maltose. Volatile fatty acid (VFA) production. Results from the two cultures shown in Fig. 7.

determinations were made at dilution rates of 0.10 and $0.21 \mathrm{hr}^{-1}$. These showed that the ammonia disappearing from the medium was equivalent to the bacterial nitrogen formed $\left(\mathrm{NH}_{3}-\mathrm{N}\right.$ was an average of $104 \%$ of cell $\left.\mathrm{N}\right)$, so that the bacterium was using ammonia in preference to the amino acids of the tryptose. This type of nitrogen utilization has been found with other rumen bacteria (see review by Hungate, Bryant \& Mah, 1964). Although the ammonia in the medium was rather less than that calculated from the constituent salt concentrations it was still present in excess in the culture and so could not have been limiting the growth of the bacteria.

The original strain of Bacteroides amylophilus used in the cultures described above changed in stock cultures in that it became slower growing, and it was found impossible to run continuous cultures over the range of dilution rates previously used. Further cultures were then made with a second strain which had been classified by the usual tests as identical to the previous one. This second strain grew over a similar range of dilution rates and produced the same fermentation products and enzymes, but it 
differed in the slope of the culture turbidity/dry weight relationship, giving a higher turbidity for the same dry weight. Also at dilution rates round about $0.3 \mathrm{hr}^{-1}$ the cultures foamed more than did the previous ones and at the high culture turbidities found here some $30 \%$ of the bacterial mass was a slime excreted into the culture medium. This second strain was used to continue and confirm the observations on enzyme activities begun with the previous strain. In a run of $1000 \mathrm{hr}$ the total amylase and protease activities per $\mathrm{ml}$. of the culture were measured at seven dilution rates between 0.09 and $0.41 \mathrm{hr}^{-1}$ and corrected to activity per unit weight of bacteria in the culture. Both the protease and amylase activities showed a peak at a dilution rate about $0.2 \mathrm{hr}^{-1}$ and the amylase activity showed a second peak at $0.09 \mathrm{hr}^{-1}$ or less. A culture was run at a dilution rate of $0.283 \pm 0.006 \mathrm{hr}^{-1}$ for $490 \mathrm{hr}$ and the culture was adjusted to seven values between $\mathrm{pH} 5 \cdot 1$ and 6.8. At $\mathrm{pH} 6.8$ the culture washed out and at $\mathrm{pH} 5 \cdot 1$ a very granular growth occurred with a variable culture turbidity. At all intermediate $\mathrm{pH}$ values the culture turbidity was the same. Amylase activity showed a maximum at a culture $\mathrm{pH}$ of $6 \cdot 1$. Protease activity increased rapidly between pH 6.6 and 6.4 and then showed a slight increase as the culture changed to $\mathrm{pH} 5 \cdot 1$. The fermentation products also changed, the amount of volatile fatty acids produced per mole of maltose utilized showing a maximum at $\mathrm{pH} 5 \cdot 8$. Succinic acid was not determined.

\section{DISCUSSION}

The results given here again show that it is possible to grow strictly anaerobic bacteria for prolonged periods in continuous culture, but the results of the Eh measurements indicate why care must be taken to eliminate even the slightest traces of oxygen from both continuous and batch cultures. The inability of Bacteroides amylophilus to reduce the medium agrees with some unpublished experiments where we found that suspensions of Selenomas ruminantium, Bacterium 5S, Ruminococcus albus and $B$. amylophilus showed no oxygen uptake in manometric experiments, whereas rumen anaerobes such as Veillonella species and Peptostreptococcus elsdenii, which can grow at higher culture Eh values than the former bacteria, showed a rapid oxygen uptake, as did the clostridia which were tested. Presumably bacteria such as these latter, which are found in comparatively small numbers in the rumen, together with some facultative anaerobes, are responsible for the oxygen uptake of rumen contents and the preservation of an Eh suitable for the predominant bacteria (typified by the former group) in spite of the air introduced into the rumen during feeding. In cases where volatile fatty acids (VFA) and lactic or succinic acids are the fermentation products the proportions of VFA to lactic or succinic acids alter with growth rate. The results obtained here with $\mathrm{pH}$-controlled cultures support the suggestion made previously (Hobson, 1965a) that the $\mathrm{pH}$ range for optimum growth of bacterium $5 \mathrm{~S}$ is small (about $\mathrm{pH}$ 5.7-7). $B$. amylophilus will grow at a lower $\mathrm{pH}$ than $5 \mathrm{~S}$ or $\mathrm{S}$. ruminantium (Hobson, 1965a) and although the rumen $\mathrm{pH}$ value of the conventionally fed animal does not usually go below about $\mathrm{pH} 5 \cdot 7$ the rumen $\mathrm{pH}$ of animals fed on high-starch rations in which B. amylophilus may be important often decreases to as low as 5. Again confirmed are the comparatively low growth rates of the anaerobic rumen bacteria; and the maximum growth rates in batch cultures compared well with those obtained in continuous cultures. In the case of Bacterium $5 \mathrm{~S}$ the concentration of carbon dioxide in the culture atmosphere had a profound effect on growth rate, but not on yield of bacteria or 
fermentation products. Why this should be so is not apparent. Growth of Bacterium $5 \mathrm{~S}$ was also slower on fructose than on glycerol.

Hobson \& Summers (1966) reported the presence of two peaks for lipase and esterase production at different growth rates for Bacterium $5 \mathrm{~S}$ growing on fructose. The present results show that this also held for growth on glycerol. Enzyme production was also a maximum in a culture at $\mathrm{pH} 6 \cdot 6$, which was about the optimum $\mathrm{pH}$ value for growth. The results obtained with Bacteroides amylophilus indicate that the amylase and protease activities of this bacterium also vary with growth rate, and with culture $\mathrm{pH}$ value. The evidence of changes in pattern of fermentation products with growth rate presented here and in the previous paper (Hobson, 1965a) is indicative of change in production of the enzymes of the fermentative pathways. Tempest \& Herbert (1965) observed variations in rates of synthesis of the 'constitutive' oxidative enzyme systems of Torula utilis at different growth rates. Dawson (1965) observed that the intracellular amino acid pool of Candida utilis varied with growth rate during $\mathrm{C}$ - and $\mathrm{N}$-limited chemostat culture, and Wright \& Lockhart (1965) observed variations with growth rate in the antigenic composition of Escherichia coli organisms. There is thus increasing evidence for changes in the enzymic as well as the structural make-up of bacteria with growth rate as well as during growth between cell divisions.

The curve obtained by plotting bacterial concentration against dilution rate is of similar shape in all cases and like that found in previous experiments (Hobson, $1965 a$ ). However, in the case of Bacterium 5S growing on glycerol under $100 \% \mathrm{CO}_{2}$ there was a rather more abrupt washout at the higher dilution rates than found previously. This may have been due to a better control of $\mathrm{pH}$ value in the present apparatus. At dilution rates above $0.3 \mathrm{hr}^{-1}$, in the previous experiments the $\mathrm{pH}$ value rose from 6.2 to 6.6 and as this latter value is nearer the optimum for growth it may have given steady states at rather higher dilution rates than those found here. The decrease in bacterial concentration and bacterial yield at low dilution rates suggests a maintenance requirement for energy at low growth rates. Curves for bacterial concentration and dilution rate similar in shape to those found for the rumen bacteria have been found by other workers with different organisms and substrates (e.g. Wase \& Hough, 1966); perhaps this type of relationship is more common than that found for Aerobacter cloacae by Herbert, Elsworth \& Telling (1956), for which they derived theoretical equations.

In the previous paper (Hobson, 1965a) the bacterial yield ( $\left.Y_{\text {glucoses }}\right)$ of Selenomonas ruminantium was shown to be about $62 \mathrm{~g}$./mole glucose fermented at optimum growth rates, and Hungate (1963) reported a value of about $55 \mathrm{~g}$. bacteria/mole hexose fermented for Ruminococcus albus growing at one dilution rate on cellobiose with ammonia as nitrogen source. The results of the present work show that Bacterium $5 \mathrm{~S}$ has a $Y_{\text {fructose }}$ of 60 at optimum growth rate. Selenomonas ruminantium and Bacterium 5S need amino acids and were growing in a complex medium. Bacteroides amylophilus utilises ammonia as nitrogen source, and the fermentation balance suggests some $20 \%$ of the maltose was used as a source of bacterial carbon. The yield of B. amylophilus at optimum growth rate then becomes $160 \mathrm{~g}$./mole maltose fermented (from Fig. 7). The fermentation pathways of these bacteria have not been investigated in detail, but assuming that 2 ATP are generated in the production of 2 pyruvate from hexose and that 1 ATP is formed in the conversion of pyruvate to acetate, propionate or succinate, we obtain values of $Y_{\mathrm{ATP}}$ of about 20 for B. amylophilus or $S$. ruminantium 
and 15 for Bacterium $5 \mathrm{~S}$ growing on fructose. These values are higher than 10 , which is the universal value suggested initially by Bauchop \& Elsden (1960) and since found for some other bacteria. On the other hand the value for $Y_{\text {glycerol }}$ for Bacterium $5 \mathrm{~S}$ (growing on glycerol) found here and in the previous experiments is 20 , which corresponds to a value for $Y_{\mathrm{ATP}}$ of 10 , assuming that 2 ATP are formed in glycerol fermentation. These calculations also assume that the enzymes liberated into the culture medium constitute a negligible proportion of the protein synthesized by the bacterium. This would appear to be the case with $B$. amylophilus since the bacterial-nitrogen formed and ammonia-nitrogen utilized were similar. These results suggest that $Y_{\text {ATP }}$ may not be a constant even at optimum growth rates for different bacteria, and with individual types of bacteria it will obviously vary with growth rate, if some energy is used for maintenance and not bacterial growth. This latter variation again emphasizes the point that the bacterial yields in batch cultures, which we found to be less in these experiments than under optimum continuous culture conditions, cannot generally be taken as a guide to maximum yield when a maintenance requirement is involved, since they are a 'synthesis' of bacterial yields at different growth rates during the culture cycle, few if any of which may be near optimum. The high yields of B. amylophilus and $R$. albus (Hungate, 1963) suggest that little ATP energy is needed for the synthesis of cell constituents from simpler compounds, in conformity with the results of Senez (1962).

The provision of a grant from The Wellcome Trust, for part of the equipment, is gratefully acknowledged. We are also indebted to our colleague Dr T. H. Blackburn for the strains of Bacteroides amylophilus used here.

\section{REFERENCES}

ANson, M. C. (1938). Estimation of proteinase with haemoglobin. J. gen. Physiol. $22,79$.

BAUCHOP, T. \& ELSDEN, S. R. (1960). The growth of micro-organisms in relation to their energy supply. J. gen. Microbiol. 23, 457.

BlackBURN, T. H. (1965). Protease production by Bacteroides amylophilus, a rumen bacterium. Ph.D. Thesis. University of Aberdeen.

Blackburn, T. H. \& Hobson, P. N. (1962). Further studies on the isolation of proteolytic bacteria from the sheep rumen. J. gen. Microbiol. $29,69$.

Dawson, P. S. S. (1965). The intracellular amino-acid pool of Candida utilis during growth in batch and continuous flow cultures. Biochim. biophys. Acta 111, 51.

Hamlin, L. J. \& Hungate, R. E. (1956). Culture and physiology of a starch-digesting bacterium (Bacteroides amylophilus N.Sp.) from the bovine rumen. J. Bact. 72, 548.

Herbert, D., Elsworth, R. \& Telling, R. C. (1956). The continuous culture of bacteria; a theoretical and experimental study. J. gen. Microbiol. 14, 601.

Hobson, P. N. (1965a). Continuous culture of some anaerobic and facultatively anaerobic rumen bacteria. J. gen. Microbiol. 38, 167.

Hobson, P. N. (1965b). Continuous culture of rumen bacteria: apparatus. J. gen. Microbiol. $38,161$.

Hobson, P. N. \& Summers, R. (1966). Effect of growth rate on the lipase activity of a rumen bacterium. Nature, Lond. 209, 736.

Hungate, R. E. (1963). Polysaccharide storage and growth efficiency in Ruminococcus albus. J. Bact. 86, 848.

Hungate, R. E., Bryant, M. P. \& Mah, R. A. (1964). The rumen bacteria and protozoa. Ann. Rev. Microbiol. 18, 131.

Hungate, R. E., Smith, W. \& Clarke, R. T. J. (1966). Suitability of butyl rubber stoppers for closing anaerobic roll culture tubes. J. Bact. $91,908$.

NeLSON, N. (1944). A photometric adaptation of the Somogyi method for the determination of glucose. J. biol. Chem. 153, 375 . 
RoE, J. H. (1934). A colorimetric method for the determination of fructose in blood and urine. J. biol. Chem., $107,15$.

SENEZ, J. C. (1962). Some considerations on the energetics of bacterial growth. Bact. Rev. 26, 95.

TEMPEST, D. W. \& HeRBERT, D. (1965). Effect of dilution rate and growth-limiting substrate on the metabolic activity of Torula utilis cultures. J. gen. Microbiol. 41, 143.

Umbreit, W. W., Burris, R. H. \& STAUffer, J. F. (1957). Manometric Techniques. Minneapolis: Burgess Publishing Co.

WASE, D. A. J. \& Hough, J. S. (1966). Continuous culture of yeast on phenol. J. gen. Microbiol. 42, 13 .

WALKeR, N. E. \& CAMPBell, L. L. (1963). Effect of carbon sources on formation of $\alpha$-amylase by Bacillus stearothermophilus. J. Bact. 86, 681.

WRIGHT, W. C. (1960). A flow regulator for automatic pH control. J. appl. Bact. 23, 291.

WRIGHT, D. N. \& LOCKHART, W. R. (1965). Environmental control of cell composition in Escherichia coli. J. Bact. 89, 1026. 